\title{
Strafrecht
}

\section{De uitleg van het begrip rechterlijke autoriteit bij de uitvaardiging van een Europees arrestatiebevel}

\author{
Mr. dr. J.W. van der Hulst*
}

Op 27 mei 2019 heeft het Hof van Justitie bij prejudiciële beslissing in drie zaken een uitspraak gedaan over de uitleg van het begrip 'rechterlijke autoriteit' in verband met het uitvaardigen van een Europees arrestatiebevel. Met een rechterlijke autoriteit wordt volgens het Hof van Justitie niet bedoeld het openbaar ministerie van een lidstaat dat niet onafhankelijk is van de uitvoerende macht, met name de minister van Justitie. Dit betekent dat in Nederland de Overleveringswet moet worden gewijzigd in de zin dat het uitvaardigen van een EAB voortaan is voorbehouden aan een rechterlijke autoriteit. Ook de Rechtbank Amsterdam moet zich beraden op de behandeling van lopende verzoeken tot overlevering afkomstig van niet-rechterlijke autoriteiten van andere lidstaten.

Hv7 27 mei 2019, gevoegde zaken C-508/18 en C-82/19 PPU, OG en PI, ECLI:EU:C:2019:456 en Hv7 27 mei 2019, zaak C-509/18, Minister for Fustice and Equality/PF, ECLI:EU:C:2019:457.

\section{Inleiding}

In 2002 is de procedure van uitlevering tussen lidstaten van de Europese Unie vervangen door een procedure van overlevering zoals voorzien in het Kaderbesluit 2002/584/JBZ (hierna: KEAB). ${ }^{1}$ Met dit KEAB is een vereenvoudigde en efficiënte regeling voor overlevering van personen gecreëerd. Deze procedure beoogt de justitiële samenwerking te vergemakkelijken en te bespoedigen en daardoor bij te dragen aan een ruimte van vrijheid, veiligheid en rechtvaardigheid die berust op de hoge mate van vertrouwen die tussen de lidstaten moet

Mr. dr. J.W. (Jaap) van der Hulst is universitair docent Strafrecht aan de Erasmus Universiteit Rotterdam.

1. PbEU 2002, L 190/1, zoals gewijzigd bij kaderbesluit 2009/299/JBZ van de Raad van 26 februari 2009, PbEU 2009, L 81/24. bestaan. ${ }^{2}$ Dit betekent dat de klassieke samenwerking van uitlevering tussen de lidstaten is vervangen door een vrij verkeer van beslissingen in strafzaken via een Europees arrestatiebevel (EAB). ${ }^{3}$ Dit EAB is een eerste tastbare toepassing op strafrechtelijk gebied van het beginsel van wederzijdse erkenning dat door de Europese Raad als hoeksteen van de strafrechtelijke samenwerking wordt beschouwd. Met de invoering van de regeling van overlevering van verdachte en veroordeelde personen is beoogd om een oplossing te vinden voor de complexiteit en het tijdverlies die inherent zijn aan uitleveringsprocedures. ${ }^{4}$ Verdachte personen worden overgeleverd met het oog op een strafvervolging in een andere lidstaat en veroordeelde personen ter uitvoering van een in een andere lidstaat opgelegde vrijheidsbenemende straf of maatregel (art. 1 lid 1 KEAB). ${ }^{5}$ Daartoe voorziet het $\mathrm{KEAB}$ in een procedure tussen rechterlijke autoriteiten van een lidstaat en wordt de rol van centrale autoriteiten

2. HvJ 5 april 2016, gevoegde zaken C-404/15 en C-659/15 PPU, Aranyosi en Cãldãraru, ECLI:EU:C:2016:198, punt 76 en HvJ 1 juni 2016, zaak C-241/15, Bob-Dogi, ECLI:EU:C:2016:385, punt 32.

3. Een uitgebreide beschrijving van de uitleverings- en overleveringsprocedure van de hand van V.H. Glerum en N. Rozemond is te vinden in: R. van Elst en E. van Sliedrecht (red.), Handboek Internationaal strafrecht, Deventer: Kluwer 2015, hoofdstuk 4 en 5, p. 163-333. Zie ook A. Klip, European Criminal Law, Antwerpen: Intersentia 2016, A. Suominen, The Principle of Mutual Recognition in Cooperation in Criminal Matters, Antwerpen: Intersentia 2011, V. Mitsilegas, EU Criminal Law after Lisbon, Oxford: Hart Publishing 2018 en T. van den Brink en T. Marguery, 'Hogere evenwichtskunst in het Europees Aanhoudingsbevel. Meer rechtsbescherming en ook meer Europa?', SEW 2018/2, p. 46-54.

4. Rechters en officieren van justitie in Nederland zijn het erover eens dat overlevering een enorme vooruitgang is ten opzichte van de vaak als moeizaam en langdurig ervaren uitleveringspraktijk: E. Kurtovic en P. Langbroek, ‘Uitgeleverd aan overlevering? De Nederlandse overleveringspraktijk beschreven, gevolgd door een discussie over de effectuering van fundamentele rechten van verdachten en veroordeelden', DD 2010/51, p. 840 en M. Luchtman, Transnationale rechtshandhaving. Over fundamentele rechten in de Europese strafrechtelijke samenwerking (oratie Utrecht), Den Haag: Boom juridisch 2017, p. 6.

5. HvJ 21 oktober 2010, zaak C-306/09, B., ECLI:EU:C:2010:626, punt 49 
zoals de minister van Justitie en Veiligheid beperkt tot het verlenen van praktische en administratieve bijstand (overweging 9 preambule bij het KEAB). De beslissing over de uitvaardiging van een $\mathrm{EAB}$ wordt genomen door een rechterlijke autoriteit van de lidstaat die een persoon opeist voor een strafvervolging of ter uitvoering van een opgelegde vrijheidsbenemende straf of maatregel (art. 1 lid $1 \mathrm{KEAB}) .{ }^{6}$ Deze rechterlijke autoriteit wordt daartoe bevoegd verklaard krachtens het recht van de uitvaardigende lidstaat (art. 6 lid $1 \mathrm{KEAB}$ ). Beslissingen over de tenuitvoerlegging van een $\mathrm{EAB}$ mogen pas worden genomen na een toereikende controle, wat betekent dat een rechterlijke autoriteit van de lidstaat waar de opgeëiste persoon is aangehouden, dient te beslissen of deze al dan niet wordt overgeleverd (overweging 8 preambule bij het KEAB). De rechterlijke autoriteit die bevoegd is het EAB uit te voeren wordt aangewezen krachtens het recht van de uitvoerende lidstaat (art. 6 lid $2 \mathrm{KEAB})$. Deze autoriteit is in de meeste lidstaten een rechter. ${ }^{7}$ In Nederland is deze autoriteit de overleveringskamer van de Rechtbank Amsterdam die op vordering van de officier van justitie die een uitgevaardigd EAB heeft ontvangen dient te beslissen of een in Nederland op grond van een EAB aangehouden persoon al dan niet mag worden overgeleverd (art. 1 sub $g$ jo. 22 lid 1 jo. 23 lid 2 Overleveringwet (OW)).

\section{De rol van de officier van justitie}

Bij de invoering van de op dit KEAB gebaseerde Overleveringswet is Nederland ervan uitgegaan dat een EAB mag worden uitgevaardigd door een justitiële autoriteit (art. 1 sub b OW). Dit betekent dat een EAB in Nederland wordt uitgevaardigd door een officier van justitie, waarbij elke officier van justitie kan fungeren als uitvaardigende justitiële autoriteit (art. $44 \mathrm{OW}){ }^{8}$ Tijdens de onderhandelingen over de totstandkoming van het $\mathrm{KEAB}$ is door Nederland uitdrukkelijk naar voren gebracht dat in navolging van de toen bestaande uitleveringspraktijk zowel rechters als leden van het openbaar ministerie EAB's zouden mogen uitvaardigen. ${ }^{9}$ Dit standpunt vloeit voort uit de opvatting dat in Nederland het openbaar ministerie behoort tot de rechterlijke macht. De officier van justitie onderscheidt zich als lid van de rechterlijke macht van rechters omdat hij niet met rechtspraak is belast (art. 1 sub b onder 7 Wet op de rechterlijke organisatie (Wet RO)). ${ }^{10}$ Dit onderscheid is

6. Dit EAB moet zijn gebaseerd op een apart nationaal aanhoudingsbevel: Bob-Dogi, punt 68.

7. Zie nader de verklaringen van lidstaten afgelegd op grond van art. 6 lid 3 van het $K E A B$, te raadplegen via www.ejn-crimjust.europa. eu.judicial.library.

8. Per jaar worden er ongeveer 700 EAB's uitgevaardigd door Nederland, waarvan ongeveer 250 resulteren in aanhouding en eventueel overlevering van de opgeëiste persoon: Kamerstukken // 2018/10, 35224, 3, p. 8.

9. Kamerstukken I/ 2018/19, 35224, 3, p. 3

10. Uit art. 116 en 117 Grondwet is af te leiden dat er ook leden van de rechterlijke macht zijn die niet met rechtspraak zijn belast. voor het uitvaardigen van een EAB niet van belang, omdat het hierbij niet gaat om rechtspraak. Nederland accepteert eveneens al meer dan vijftien jaar dat een $\mathrm{EAB}$ wordt uitgevaardigd door een justitiële autoriteit van een andere lidstaat (verg. art. $5 \mathrm{OW}$ ). Ook in andere lidstaten is geaccepteerd dat een justitiële autoriteit een EAB mag uitvaardigen. ${ }^{11}$ Dit maakt duidelijk dat overlevering een samenwerkingsvorm is die uitsluitend tussen de justitiële autoriteiten van de lidstaten plaatsvindt. ${ }^{12}$ Opmerkelijk is dat het KEAB het heeft over een 'rechterlijke autoriteit' en de OW over een 'justitiële autoriteit'. Uit de wetsgeschiedenis blijkt niet waarom de Nederlandse wetgever is afgeweken van de terminologie van het KEAB. Volgens Glerum berust het KEAB onder meer op artikel 31 lid 1 sub a (oud) van het Verdrag betreffende de Europese Unie (VEU), dat gezamenlijk optreden van de lidstaten mogelijk maakt met het oog op het vergemakkelijken en bespoedigen van de samenwerking tussen de bevoegde ministeries en de justitiële of gelijkwaardige autoriteiten van de lidstaten met betrekking tot procedures en de tenuitvoerlegging van beslissingen. De opstellers van het KEAB hebben willen aansluiten bij de terminologie van dit artikel en in de Nederlandse vertaling van het KEAB is daarbij het begrip 'rechterlijke autoriteit' abusievelijk in de plaats gekomen van 'justitiële autoriteit'. ${ }^{13}$ Uitgaande van het $\mathrm{KEAB}$ dient de uitvaardiging van een EAB te geschieden door een 'rechterlijke autoriteit'. Daarbij is cruciaal wat er naar EU-recht onder een 'rechterlijke autoriteit' wordt verstaan.

\section{Rechterlijke autoriteit}

Artikel 6 lid 1 KEAB heeft het over de 'rechterlijke autoriteit' die 'bevoegd is om een EAB uit te vaardigen krachtens het recht van de uitvaardigende lidstaat'. Dit zou zo kunnen worden geinterpreteerd dat het lidstaten vrij staat te bepalen welke autoriteit binnen hun grondgebied als rechterlijke autoriteit kan worden aangemerkt die bevoegd is een EAB uit te vaardigen. Volgens de Europese Commissie is het bij invoering van het KEAB aan de lidstaten overgelaten om de tot uitvaardiging van een $\mathrm{EAB}$ bevoegde autoriteiten aan te wijzen, waarbij het in strijd is met het KEAB om een orgaan van de regering als autoriteit aan te wijzen. ${ }^{14}$ Deze interpretatie

11. Hof van Cassatie van België 15 september 2009, P.09.1363.N over een vervolgende autoriteit uit Duitsland die een EAB heeft uitgevaardigd en United Kingdom Supreme Court 30 mei 2012, Assange $v$ The Swedish Prosecution Authority, [2012] UKSC22: 'A prosecutor properly falls within the description "judicial authority" and is capable of being the judicial authority competent to issue an EAW under article 6 (KEAB) if the law of the State so provides.'

12. Kamerstukken // 2002/03, 29042, 3, p. 17.

13. V.H. Glerum, De weigeringsgronden bij uitlevering en overlevering (diss. Amsterdam VU), Nijmegen: Wolf Legal Publishers 2013, p. 53 en 54.

14. Annex to the report from the Commission based on article 34 of the Council Framework Decision of 13 June 2002 on the European arrest warrant and the surrender procedure between Member States, SEC (2006)79, p. 14. 
is te verenigen met de opvatting van het Hof van Justitie die ruimte laat voor een uitzondering op het algemene uitgangspunt dat voorschriften van Unierecht in de hele Unie autonoom en uniform moeten worden uitgelegd. Van dit uitgangspunt mag worden afgeweken indien voor de betekenis van een voorschrift van het Unierecht uitdrukkelijk naar het recht van de lidstaten wordt verwezen. ${ }^{15}$ Aanvankelijk was de opvatting in Nederland dat met de regeling in artikel 6 lid $1 \mathrm{KEAB}$ sprake was van een dergelijke uitzondering omdat de aanduiding als 'rechterlijke autoriteit' door het recht van een lidstaat bepaalt of een autoriteit in de eigen lidstaat een rechterlijke autoriteit is. ${ }^{16}$ Het Hof van Justitie heeft echter vastgesteld dat artikel 6 lid $1 \mathrm{KEAB}$ overeenkomstig het beginsel van procedurele autonomie van de lidstaten weliswaar verwijst naar het recht van de lidstaten, maar dat deze verwijzing slechts ziet op de aanduiding van de rechterlijke autoriteit die bevoegd is om een EAB uit te vaardigen. Deze verwijzing heeft geen betrekking op de definitie en betekenis van het begrip 'rechterlijke autoriteit' als zodanig en kan dus niet worden overgelaten aan de beoordeling van elke lidstaat. ${ }^{17}$ Het begrip 'rechterlijke autoriteit' is volgens het Hof van Justitie een autonoom Unierechtelijk begrip waarvan de invulling niet kan worden overgelaten aan de lidstaten. Daarbij omvat het begrip 'rechterlijke autoriteit' rechters en rechterlijke instanties en ook autoriteiten in de lidstaten die deelnemen aan de strafrechtsbedeling. Dit vloeit voort uit de scheiding van machten, de scheiding tussen justitiële en politiële samenwerking in het EU-recht en het doel van het $\mathrm{KEAB}$ dat verlangt dat het uitvaardigen van een KEAB moet worden onderworpen aan een rechterlijke toetsing. ${ }^{18}$ Dit betekent dat een orgaan van de uitvoerende macht van een lidstaat, zoals een ministerie, niet als 'rechterlijke autoriteit' kan worden aangemerkt omdat de uitvaardiging van een EAB onderworpen moet zijn aan rechterlijk toezicht ter bescherming van fundamentele rechten van de opgeëiste persoon. ${ }^{19}$ Ook politiediensten kunnen niet als 'rechterlijke autoriteit' worden aangemerkt. ${ }^{20}$ Indien het echter gaat om een door de politie uitgevaardigd $\mathrm{EAB}$ dat door het openbaar ministerie is getoetst en bevestigd is er wel sprake van een 'rechterlijke beslissing' in de zin van artikel 8 lid 1 sub c KEAB. ${ }^{21}$ In drie hierna te bespreken uitspraken heeft het Hof van Justitie de uitleg van het begrip 'rechterlijke autoriteit' in artikel 6 lid $1 \mathrm{KEAB}$ nader verdiept. Daarbij heeft het Hof van Justitie tevens een oordeel gegeven over het uitvaardigen van een EAB door (een lid van) het openbaar ministerie.

15. HvJ 17 juli 2008, zaak C-66/08, Kozlowski, ECLI:EU:C:2008:437, NJ 2008/586, m.nt. M.J. Borgers, punt 42.

16. Glerum 2013, p. 54

17. HvJ 10 november 2016, zaak C-452/16 PPU, Poltorak, ECLI:EU:C: 2016:858, punt 30 en 31.

18. Poltorak, punt 38 en 44-46.

19. HvJ 10 november 2016, zaak C-477/16 PPU, Kovalkovas, ECLI:EU:C: 2016:861, punt 35 en 36

20. Poltorak, punt $34,43,45$ en 46.

21. HvJ 10 november 2016, zaak C-453/16 PPU, Özçelik, ECLI:EU:C: 2016:860, punt 39 .

\section{Voorgeschiedenis}

In de zaken C-508/18 en C-82/19 PPU gaat het om twee EAB's die zijn uitgevaardigd door de officier van justitie bij het Landgericht Lübeck in zaak C-508/18 en door de officier van justitie in Zwickau in zaak C-82/19 PPU, beide met het oog op een tegen de opgeëiste personen ingestelde strafvervolging in Duitsland. Beide opgeëiste personen voeren het verweer dat het uitgevaardigde $\mathrm{EAB}$ ongeldig is omdat het openbaar ministerie in Duitsland geen 'rechterlijke autoriteit' is in de zin van artikel 6 lid $1 \mathrm{KEAB}$ en deel uitmaakt van een door de minister van Justitie geleide administratieve hiërarchie, zodat er een risico is van politieke inmenging in de overleveringsprocedures. De bij de twee zaken betrokken Ierse rechters hebben daarop om aanvullende informatie gevraagd over de juridische status van het openbaar ministerie. Het openbaar ministerie van Lübeck en het openbaar ministerie in Zwickau hebben hierop geantwoord dat het openbaar ministerie naar Duits recht een orgaan van de strafrechtsbedeling is, net als de nationale rechterlijke instanties, en dat het is belast met de vervolging en de deelname aan de strafprocedure. Daarbij heeft de minister van Justitie van de betreffende deelstaat geen instructiebevoegdheid ten aanzien van het openbaar ministerie. Deze instructiebevoegdheid komt alleen toe aan de procureur-generaal van het openbaar ministerie die aan het hoofd staat van dit ministerie in de betreffende deelstaat. Wel kan de minister van Justitie een instructiebevoegdheid uitoefenen jegens de procureur-generaal, binnen de grenzen van de Duitse grondwet en het legaliteitsbeginsel. In beide zaken is door de minister van Justitie geen enkele instructie gegeven aan de procureur-generaal en heeft de procureur-generaal evenmin enige instructie gegeven aan het openbaar ministerie van Lübeck en Zwickau.

In zaak C-509/18 gaat het eveneens om een in Ierland verblijvende Litouws staatsburger wiens overlevering wordt gevraagd door de procureur-generaal van Litouwen met het oog op een strafvervolging voor een 'gewapende overval'. De opgeëiste persoon voert het verweer dat het op hem betrekking hebbende EAB ongeldig is omdat de procureur-generaal van Litouwen geen 'rechterlijke autoriteit' is in de zin van artikel 6 lid 1 van het KEAB. Deze procureur-generaal stelt in een reactie hierop dat hij onafhankelijk is van zowel de rechterlijke macht als de uitvoerende macht, met inbegrip van de minister van Justitie.

De hoogste Ierse rechter heeft de behandeling van deze drie zaken geschorst en het Hof van Justitie gevraagd om een prejudiciële beslissing te nemen op grond van artikel 267 Verdrag betreffende de werking van de Europese Unie (VWEU) over de betekenis van het begrip 'uitvaardigende rechterlijke autoriteit' in artikel 6 lid $1 \mathrm{KEAB}$. Daarnaast wordt de vraag voorgelegd welke criteria een nationale rechter moet hanteren om te bepalen of een openbaar ministerie al dan niet een 'rechterlijke autoriteit' is in de zin van artikel 6 lid 1 KEAB. Tevens wordt gevraagd of het openbaar ministerie in 
Duitsland en de procureur-generaal van Litouwen op basis van deze criteria kunnen worden aangemerkt als een 'rechterlijke autoriteit' die bevoegd is om een EAB uit te vaardigen.

\section{Toetsingskader Hof van Justitie}

Het Hof van Justitie voegt de zaken C-508/18 en C-82/19 PPU omdat de naar aanleiding van deze zaken gestelde vragen inhoudelijk samenvallen. Daarbij gaat het in de kern om de vraag of het begrip 'rechterlijke autoriteit' in de zin van artikel 6 lid $1 \mathrm{KEAB}$ zodanig moet worden uitgelegd dat het betrekking heeft op openbare ministeries van een lidstaat die bevoegd zijn voor strafvervolging en zich in een ondergeschikte positie bevinden ten opzichte van een orgaan van de uitvoerende macht van deze lidstaat, zoals een minister van Justitie, en die in een individueel geval rechtstreeks of indirect kunnen worden aangestuurd door of instructies kunnen ontvangen van dat orgaan bij de vaststelling van een besluit over de uitvaardiging van een EAB. ${ }^{22} \mathrm{Bij}$ de beantwoording van deze vraag brengt het Hof van Justitie in herinnering dat zowel het beginsel van wederzijds vertrouwen als dat van wederzijdse erkenning in het Unierecht van fundamenteel belang is. Het beginsel van wederzijds vertrouwen vereist dat elke lidstaat, behoudens uitzonderlijke omstandigheden, ervan uitgaat dat alle andere lidstaten het Unierecht en in het bijzonder de door dat recht erkende grondrechten in acht nemen. ${ }^{23}$ Het EAB als toepassing van het beginsel van wederzijdse erkenning in artikel 1 lid 2 KEAB brengt met zich mee dat lidstaten zich ertoe verbinden overeenkomstig de bepalingen van het KEAB elk EAB ten uitvoer te leggen. Het beginsel van wederzijdse erkenning veronderstelt echter dat alleen EAB's in de zin van artikel 1 lid $1 \mathrm{KEAB}$ ten uitvoer worden gelegd. Het moet dan volgens artikel 6 lid $1 \mathrm{KEAB}$ gaan om een $\mathrm{EAB}$ dat is uitgevaardigd door een rechterlijke autoriteit van de uitvaardigende lidstaat die tot een dergelijke uitvaardiging bevoegd is krachtens het recht van de uitvaardigende lidstaat. Hoewel de aanwijzing van zo'n rechterlijke autoriteit berust bij de lidstaten, kan de betekenis en strekking van deze autoriteit niet worden overgelaten aan de beoordeling van elke lidstaat en dient het begrip 'rechterlijke autoriteit' in de gehele Unie autonoom en uniform te worden uitgelegd. ${ }^{24}$ Het Hof van Justitie heeft reeds eerder geoordeeld dat het begrip 'rechterlijke autoriteit' niet slechts de rechters en rechterlijke instanties van een lidstaat omvat, maar breder is en ook autoriteiten kan omvatten die in de betrokken lidstaat deelnemen aan de strafrechtsbedeling, in tegenstelling tot met name ministeries of politiediensten, die

22. HvJ 27 mei 2019, gevoegde zaken C-508/18 en C-82/19 PPU, OG en PI, ECLI:EU:C:2019:456, punt 42.

23. OG en Pl, punt 43 onder verwijzing naar HvJ 25 juli 2018 zaak C-216/18 PPU, LM, ECLI:EU:C:2018:586, punt 36.

24. OG en $\mathrm{Pl}$, punt $44-49$. deel uitmaken van de uitvoerende macht. ${ }^{25}$ Dit betekent dat het begrip 'rechterlijke autoriteit' ook autoriteiten van een lidstaat kan omvatten die deelnemen aan de strafrechtsbedeling in een lidstaat, zonder dat zij rechters of rechterlijke instanties zijn. Een autoriteit zoals een openbaar ministerie dat beschikt over de bevoegdheid om een strafvervolging in te stellen tegen een verdachte teneinde hem voor de strafrechter te brengen, moet worden geacht deel te nemen aan de rechtsbedeling in de betrokken lidstaat. Dit geldt volgens het Hof van Justitie ook voor het Duitse openbaar ministerie. ${ }^{26}$

\section{Onafhankelijkheid rechterlijke autoriteit}

Daarnaast is het volgens het Hof van Justitie van belang dat openbare ministeries voldoen aan het vereiste van onafhankelijkheid ten opzichte van de uitvoerende macht, met inbegrip van de minister van Justitie. Wanneer een EAB wordt uitgevaardigd met het oog op de aanhouding en overlevering van een opgeëiste persoon door een andere lidstaat om een strafvervolging in te stellen, moeten rechterlijke autoriteiten van de uitvaardigende lidstaat erop toezien dat die persoon al in een eerste stadium van de procedure het voordeel van procedurele waarborgen en de grondrechten dient te kunnen genieten, met name met het oog op de vaststelling van een nationaal aanhoudingsbevel. De regeling van het EAB omvat volgens het Hof van Justitie op twee niveaus bescherming van de procedurele en grondrechten van de opgeëiste persoon. Het eerste niveau bestaat uit de rechterlijke bescherming bij de vaststelling van een nationale beslissing, zoals een nationaal aanhoudingsbevel. Het tweede niveau heeft betrekking op de uitvaardiging van het $\mathrm{EAB}$, die kort na vaststelling van de nationale rechterlijke beslissing kan plaatsvinden. Omdat de uitvaardiging van een EAB het in artikel 6 van het Handvest van de grondrechten van de EU neergelegde recht op vrijheid van de opgeëiste persoon kan aantasten, houdt deze bescherming in dat op minstens een van de twee niveaus van die bescherming een beslissing wordt genomen die voldoet aan de vereisten die inherent zijn aan een effectieve rechterlijke bescherming. Hieruit volgt dat wanneer het recht van een uitvaardigende lidstaat de bevoegdheid om een EAB uit te vaardigen toekent aan een autoriteit die weliswaar deelneemt aan de rechtsbedeling in die lidstaat maar geen rechter of rechterlijke instantie is, de nationale rechterlijke beslissing, zoals een nationaal aanhoudingsbevel waar het EAB op is gebaseerd, zelf moet voldoen aan dergelijke vereisten. Wanneer is voldaan aan deze vereisten kan ten aanzien van de uitvoerende rechterlijke autoriteit worden gewaarborgd dat de beslissing om een EAB uit te vaardigen met het oog op een strafver-

OG en PI, punt 50 onder verwijzing naar Poltorak, punt 33 en 35 en Kovalkovas, punt 34 en 36.

26. OG en $\mathrm{Pl}$, punt 51-61. 
volging is gebaseerd op een nationale procedure die onderworpen is aan rechterlijk toezicht en dat de opgeëiste persoon de waarborgen die voortvloeien uit de grondrechten en de fundamentele rechtsbeginselen als bedoeld in artikel 1 lid $3 \mathrm{KEAB}$ heeft genoten. Het tweede niveau van bescherming van de rechten van de opgeëiste persoon houdt in dat de rechterlijke autoriteit die bevoegd is een $\mathrm{EAB}$ uit te vaardigen in het bijzonder controleert of de voor de uitvaardiging noodzakelijk voorwaarden aanwezig zijn en onderzoekt of de uitvaardiging evenredig is. ${ }^{27} \mathrm{De}$ 'uitvaardigende rechterlijke autoriteit' in de zin van artikel 6 lid 1 KEAB moet in staat zijn die taak objectief uit te oefenen zonder daarbij het risico te lopen dat de uitvoerende macht haar beslissingsbevoegdheid aanstuurt of met betrekking tot die bevoegdheid instructies geeft, zodat het geen enkele twijfel lijdt dat het besluit tot uitvaardiging van het EAB uitgaat van die autoriteit en niet van de uitvoerende macht. De uitvaardigende rechterlijke autoriteit moet de zekerheid kunnen bieden dat zij bij de uitvaardiging van het $\mathrm{EAB}$ op onafhankelijke wijze optreedt. Deze onafhankelijkheid vereist dat er voorschriften bestaan die waarborgen dat de uitvaardigende rechterlijk autoriteit bij de vaststelling van een beslissing tot uitvaardiging van een $\mathrm{EAB}$ geen enkel risico loopt om te worden onderworpen aan een individuele instructie van de uitvoerende macht. Wanneer het recht van een uitvaardigende lidstaat de bevoegdheid om een EAB uit te vaardigen toekent aan een autoriteit die weliswaar aan de rechtsbedeling in die lidstaat deelneemt maar zelf geen rechter of rechterlijk instantie is, moet bovendien de beslissing om een EAB uit te vaardigen en met name de evenredigheid van die beslissing in de betreffende lidstaat het voorwerp kunnen uitmaken van een beroep in rechte dat volledig voldoet aan de vereisten die voortvloeien uit een effectieve rechterlijke bescherming. ${ }^{28}$

\section{Het Duitse openbaar ministerie is geen rechterlijke autoriteit}

Op basis van de hiervoor weergegeven overwegingen onderzoekt het Hof van Justitie of de openbare ministeries in Duitsland kunnen worden aangemerkt als een 'rechterlijke autoriteit' in de zin van artikel 6 lid 1 KEAB ${ }^{29}$ Het stelt vast dat Duitse openbare ministeries gehouden zijn tot objectiviteit, maar dat de minister van Justitie beschikt over een instructiebevoegdheid ten opzichte van die openbare ministeries en dat die bevoegdheid de mogelijkheid biedt om rechtstreeks invloed uit te oefenen op de beslissing van het openbaar ministerie om al dan niet een $\mathrm{EAB}$ uit te vaardigen en

OG en $P I$, punt 65-71.

28. OG en $\mathrm{Pl}$, punt $73-75$.

29. Zie over het uitvaardigen van een EAB in Duitsland: A. Kaufmann en M. Sehl, 'Deutsche Staatsanwaltschaft nicht unabhängig genug', Legal Tribune Online 27 mei 2019, www.eugh-europaeischer-haftbefehlfolgen-deutsche-staatsanwaltschaft, p. 2 en 3. ook om de evenredigheid van deze uitvaardiging te onderzoeken. ${ }^{30}$ Het Duitse recht voorziet volgens de Duitse regering in garanties die grenzen kunnen stellen aan deze instructiebevoegdheid, zodat die bevoegdheid zelden wordt toegepast. Niettemin stelt het Hof van Justitie vast dat deze garanties in ieder geval niet helemaal kunnen uitsluiten dat de beslissing van een openbaar ministerie om een EAB uit te vaardigen in een individueel geval deel kan uitmaken van een (mondelinge) instructie van de minister van Justitie van een deelstaat. Door het risico dat de uitvoerende macht in een individueel geval invloed kan uitoefenen op het openbaar ministerie kan niet worden gewaarborgd dat het openbaar ministerie voldoet aan de vereiste zekerheid dat het bij de uitvaardiging van het EAB op onafhankelijke wijze optreedt. Hieraan doet niet af dat tegen de beslissing van een openbaar ministerie om een EAB uit te vaardigen door de opgeëiste persoon een rechtsmiddel kan worden ingesteld bij een rechter. Het instellen van dit rechtsmiddel laat volgens de Duitse wet de mogelijkheid open van een eventuele instructie van de minister van Justitie ten aanzien van het openbaar ministerie bij de uitvaardiging van een EAB. ${ }^{31}$ Het Hof van Justitie is van oordeel dat, omdat de betrokken openbare ministeries het risico lopen dat zij worden beïnloed door de uitvoerende macht bij een beslissing om een $\mathrm{EAB}$ uit te vaardigen, zij niet beantwoorden aan de eis van onafhankelijkheid waardoor zij niet kunnen worden aangemerkt als 'uitvaardigende rechterlijke autoriteit' in de zin van artikel 6 lid $1 \mathrm{KEAB}^{32}$ Daarbij speelt geen rol dat bij de uitvaardiging van het EAB in beide zaken de betrokken openbare ministeries geen individuele instructies hebben ontvangen van de ministers van Justitie van de betrokken deelstaten. ${ }^{33}$ Hiermee volgt het Hof van Justitie de conclusie van advocaat-generaal Campos Sánchez-Bordona in de zaken $O G$ en PI, die overweegt dat artikel 6 lid $1 \mathrm{KEAB}$ met het begrip 'uitvaardigende rechterlijke autoriteit' niet de instelling van het openbaar ministerie omvat. ${ }^{34}$

30. Dit blijkt uit art. 146 en 147 Gerichtsverfassungsgesetz waar wordt bepaald dat een ambtenaar van het openbaar ministerie de dienstinstructies van zijn leidinggevenden in acht moet nemen. Tot die leidinggevenden behoort de federale minister van Justitie die (via de federale procureur-generaal) instructies kan geven aan de federale openbare aanklagers.

31. OG en PI, punt 76-78 en 80-87.

32. Deze opvatting heeft in Duitsland tot grote consternatie geleid. Het Duitse Bundesministerie van Justitie schat dat er per juli 2019 meer dan 5000 EAB's zijn uitgevaardigd door niet-rechterlijke autoriteiten in Duitsland. Het voornemen is om deze EAB's om te zetten in $E A B^{\prime} s$ die zijn uitgevaardigd door een Duitse rechter: A. Kaufmann, 'Deutsche Staatsanwaltschaft arbeitet auf dünen Eis', Legal Tribune Online 4 juli 2019, www.eugh-europaeischer-haftbefehl-folgen-deutsche-staatsan waltschaft, p. 2 en 3.

33. OG en PI, punt 88 en 89.

34. Conclusie A-G Campos Sánchez-Bordona 30 april 2019, gevoegde zaken C-508/18 en C-82/19 PPU, OG en PI, ECLI:EU:C:2019:337, punt 100 . Hij merkt hierbij op (in punt 1 en 2 ) dat pas in deze zaken voor het eerst de vraag is gesteld of een openbaar ministerie kan worden aangemerkt als 'rechterlijke autoriteit' in de zin van art. 6 lid 1 $\mathrm{KEAB}$. 


\section{De procureur-generaal van Litouwen is wel een rechterlijke autoriteit}

In de derde zaak, Minister for Fustice and Equality/PF, komt het Hof van Justitie op basis van dezelfde overwegingen tot een andersluidend oordeel over de procureurgeneraal van Litouwen. Uit nadere informatie van de Litouwse regering leidt het Hof van Justitie af dat de procureur-generaal van Litouwen wel kan worden aangemerkt als een 'uitvaardigende rechterlijke autoriteit' in de zin van artikel 6 lid $1 \mathrm{KEAB}$, omdat deze procureur-generaal de status heeft van openbaar anklager en daarmee structureel onafhankelijk is van de rechterlijke macht, hetgeen hem toelaat om op te treden zonder enige invloed van met name de uitvoerende macht. Dit geldt in het bijzonder wanneer hij beslist om een EAB uit te vaardigen waarbij hij verplicht is om de rechten van de opgeëiste persoon te beschermen. ${ }^{35}$

\section{Commentaar}

Met deze drie uitspraken bevestigt het Hof van Justitie dat het begrip 'rechterlijke autoriteit' in de zin van artikel 6 lid $1 \mathrm{KEAB}$ autonoom moet worden uitgelegd. De uitvaardiging van een $\mathrm{EAB}$ moet door een rechterlijke autoriteit worden gedaan, zodat de gehele procedure van overlevering onder rechterlijk toezicht staat. Dit houdt in dat een door de lidstaat aan te wijzen rechterlijke autoriteit die bevoegd is tot het uitvaardigen van een EAB volledig onafhankelijk dient te zijn van de uitvoerende macht. Dit vereiste vloeit volgens het Hof van Justitie voort uit de bescherming van de grondrechten van de opgeëiste persoon. Het lijkt mij dat het Hof van Justitie met deze opvatting een onwerkbare situatie creëert voor lidstaten waar het openbaar ministerie niet strikt is gescheiden van de uitvoerende macht. Het gaat hierbij om ten minste tien lidstaten waar sprake is van een bepaalde mate van zeggenschap van de uitvoerende macht over het openbaar ministerie dat EAB's uitvaardigt. ${ }^{36}$ Het is voor deze lidstaten lastig om op korte termijn te voorzien in een regeling die voldoet aan de door het Hof van Justitie verlangde onafhankelijkheid van de rechterlijke autoriteit die een EAB uitvaardigt. Dit is nodig omdat anders het uitvaardigen van nieuwe EAB's en lopende overleveringsprocedures gebaseerd

35. HvJ 27 mei 2019, zaak C-509/18, Minister for Justice and Equality/PF, ECLI:EU:C:2019:457, punt 55-57.

36. Op basis van door lidstaten op grond van art. 6 lid 3 KEAB afgelegde verklaringen gaat het om: Bulgarije, Frankrijk, Duitsland, Griekenland, Kroatië, Luxemburg, Nederland, Oostenrijk, Portugal en Zweden, te raadplegen via www.ejn-crimjust.europa.eujudicial.library. Het openbaar ministerie in Estland, Finland en Litouwen is bij het uitvaardigen van een $E A B$ wel volledig onafhankelijk van de uitvoerende macht: The 2019 EU Justice Scoreboard, Factsheet april 2019, https:// ec.europea.eu/info/strategy/justice-and-fundamental-rights/effectivejustice/eu-justice-scoreboard, p. 11 op door niet-rechterlijke autoriteiten uitgevaardigde EAB's onvermijdelijk vertraging zullen oplopen. Een regeling in deze lidstaten zou ofwel moeten voorzien in het volledig onafhankelijk maken van de positie van het openbaar ministerie van de uitvoerende macht of in de aanwijzing van een rechterlijke autoriteit die volstrekt onafhankelijk is. Bij deze laatste optie zijn de lidstaten gedwongen om te voorzien in een wettelijke aanpassing van de autoriteit die krachtens het nationale recht van de lidstaat bevoegd is tot het uitvaardigen van een EAB. ${ }^{37}$ Voorts is wat mij betreft de opvatting van het Hof van Justitie dat de rechterlijke autoriteit die een EAB uitvaardigt bij deze beslissing zelfs niet in abstracto mag worden beïnvloed door de uitvoerende macht, te streng. Een minder vergaande invulling van het autonome karakter van het begrip rechterlijke autoriteit' die een EAB uitvaardigt, zou ook mogelijk zijn. Het Hof van Justitie had ter bescherming van de rechten van de opgeëiste persoon ervoor kunnen kiezen om bij de beslissing van de 'rechterlijke autoriteit' die een EAB uitvaardigt te verlangen dat deze beslissing tot stand moet komen zonder enige concrete inmenging door de uitvoerende macht. Daarmee zou de onafhankelijkheid van de rechterlijke autoriteit die een $\mathrm{EAB}$ uitvaardigt eveneens zijn gewaarborgd zonder dat lidstaten op korte termijn hun wetgeving moeten aanpassen.

\section{Gevolgen voor Nederland}

De uitspraken van het Hof van Justitie nopen Nederland tot een herbezinning op de bestaande overleveringspraktijk. De Nederlandse officier van justitie die een EAB uitvaardigt, voldoet niet aan de door het Hof van Justitie vereiste onafhankelijkheid omdat de minister van Justitie een bevoegdheid heeft om algemene en bijzondere aanwijzingen te geven over de uitoefening van de taken en bevoegdheden van het openbaar ministerie (art. 127 Wet RO). De inhoud van deze aanwijzingen wordt niet door de wet beperkt vanwege de in beginsel ongelimiteerde politieke verantwoordelijkheid van de minister voor het handelen van het openbaar ministerie. ${ }^{38}$ Dat de minister een zekere distantie bewaart ten opzichte van het handelen van het openbaar ministerie is een onvoldoende garantie voor politieke beïnvloeding bij het uitoefenen van bevoegdheden die ingrijpen in grondrechten van burgers. ${ }^{39}$ Het Hof van Justitie benadrukt dat er geen enkel risico mag zijn op enige denkbare beïnvloeding door de minister van Justitie bij de vaststelling van een besluit over de uitvaardiging van een EAB. Hieruit volgt dat een Nederlandse officier van justitie niet kan worden aangemerkt als een 'rechterlijke autoriteit' die een EAB mag uitvaardigen,

37. Nederland heeft gekozen voor deze laatste optie, zie hierna onder 'Gevolgen voor Nederland'.

38. Kamerstukken II 1996/97, 25392, 3, p. 20.

39. T. Spronken, 'Officier van justitie: geen judicial authority', NJB 2019, p. 1923. 
omdat hij de daartoe vereiste onafhankelijkheid mist. ${ }^{40}$ De minister van Justitie en Veiligheid deelt deze opvatting en heeft via spoedwetgeving de Overleveringswet zodanig gewijzigd dat de rechter-commissaris, in plaats van de officier van justitie, in het vervolg zal fungeren als autoriteit die een EAB uitvaardigt. ${ }^{41}$ De officier van justitie zal de uitvaardiging van een $\mathrm{EAB}$ voortaan moeten vorderen bij de rechter-commissaris bij de Rechtbank Amsterdam of een andere rechter-commissaris. Op basis van deze vordering kan de rechter-commissaris een EAB feitelijk uitvaardigen en kan hij daarna rechtstreeks contact onderhouden met de uitvoerende autoriteit (art. $46 \mathrm{OW}){ }^{42}$ Daarbij kan hij een verzoek doen tot inbeslagneming en overdracht van voorwerpen aangetroffen bij de in het EAB opgeëiste persoon en een verzoek doen tot doorvoer, het horen en tijdelijk overbrengen van de opgeëiste persoon (art. 55-57 OW). ${ }^{43}$ Met deze beoogde wijzigingen wordt volgens de minister volledig voldaan aan de eisen die het Hof van Justitie stelt aan de onafhankelijkheid van de autoriteit die een EAB uitvaardigt. ${ }^{44}$ Hierbij is overigens afgezien van een heroverweging van de ministeriële aanwijzingsbevoegdheid van artikel 127 Wet RO. ${ }^{45}$

\section{Gevolgen voor de behandeling van EAB's bij de Rechtbank Amsterdam}

Met deze wijzigingen zijn de problemen bij de behandeling van EAB's uit andere lidstaten niet opgelost. Een eerste probleem betreft de in het verleden door de Rechtbank Amsterdam toegestane overleveringen die zijn gebaseerd op een EAB dat niet is uitgevaardigd door een 'rechterlijke autoriteit'. Het lijkt juridisch lastig om dit terug te draaien omdat door de Rechtbank Amsterdam toegestane overleveringen direct uitvoer-

40. Op basis van een uitspraak van het Hof van Justitie in 2014 kan overigens worden betwijfeld of het Nederlandse openbaar ministerie de vereiste onafhankelijkheid tegenover de minister van Justitie heeft als toetsende autoriteit in het kader van de Dataretentierichtlijn 2006/24/EG. Zie nader: M.E. de Meijer, 'Veenbranden in de rechtstaat', NBSR 2019, p. 575.

41. Deze wijziging van de Overleveringswet staat los van de voorgenomen wijzigingen van de Overleveringswet naar aanleiding van rechtspraak van het Hof van Justitie in het conceptwetsvoorstel Herimplementatie kaderbesluit Europees aanhoudingsbevel. Zie over dit conceptwetsvoorstel ook het advies van de Raad voor de rechtspraak van 12 december 2018.

42. Zie nader over de rol van de rechter-commissaris in het Nederlandse strafproces: P.P.J. van der Meij, De driehoeksverhouding in het strafrechtelijk vooronderzoek (diss. Leiden), Deventer: Kluwer 2010 en P.A.M. Verrest, Raison d'être (diss. Nijmegen), Den Haag: Boom Juridische uitgevers 2011.

43. Kamerstukken I/ 2018/19, 35224, 3, p. 4, 7 en 9.

44. Brief van de minister van Justitie en Veiligheid van 17 juni 2019, kenmerk 2628754.

45. Een dergelijke heroverweging wordt door zowel het openbaar ministerie als de Raad voor de rechtspraak geadviseerd: Kamerstukken // 2018/19, 35224,3, p. 5 baar zijn (art. 29 lid 1 OW). ${ }^{46}$ Voorts is enkel voorzien in de mogelijkheid van schadevergoeding in gevallen waarin de overlevering is geweigerd (art. 67 lid $1 \mathrm{OW}$ ). Een tweede probleem vormt de behandeling van uitgevaardigde EAB's die nog niet tot een beslissing op de verlangde overlevering hebben geleid. ${ }^{47}$ De Rechtbank Amsterdam is inmiddels diverse keren geconfronteerd met EAB's die niet zijn uitgevaardigd door een onafhankelijke rechterlijke autoriteit zoals dat begrip volgens het Hof van Justitie met ingang van 27 mei 2019 moet worden geinterpreteerd. Het gaat met name om EAB's die afkomstig zijn uit Duitsland. In de meeste van deze zaken stelt de Rechtbank Amsterdam vast dat de door de officier van justitie ingestelde vordering tot behandeling van deze EAB's niet berust op een door een rechterlijke autoriteit uitgevaardigde beslissing. ${ }^{48}$ Dit leidt ertoe dat de officier van justitie niet-ontvankelijk moet worden verklaard in zijn vordering tot het in behandeling nemen van het $\mathrm{EAB}^{49}$ en dat de overleveringsdetentie van de opgeëiste persoon veelal wordt opgeheven. ${ }^{50}$ Deze beslissingen ogen formeel juist want een opgeëiste persoon kan sinds 27 mei 2019 niet worden overgeleverd op grond van een $\mathrm{EAB}$ dat is uitgevaardigd door een niet-onafhankelijke rechterlijke autoriteit. Of er direct een niet-ontvankelijkheid van de officier van justitie moet worden uitgesproken in zijn vordering tot behandeling van een dergelijk EAB lijkt mij echter de vraag. Een alternatieve benadering zou kunnen zijn dat de officier van justitie enige tijd wordt gegund om zich te beraden op en uitleg te geven over de autoriteit die het EAB heeft uitgevaardigd en zijn positie tegenover de uitvoerende macht en de minister van Justitie in de betreffende lidstaat. Deze benadering zou een invulling geven aan de beginselen van wederzijds vertrouwen en wederzijdse erkenning die in het Unierecht van fundamenteel belang zijn en die aan de basis liggen van de overleveringsprocedure. Vanuit deze benadering is het begrijpelijk dat de Rechtbank Amsterdam in een aantal zaken van een door een Duitse autoriteit uitgevaardigd EAB de officier van justitie en de verdediging de gelegenheid geeft om zich uit te laten over de eerder besproken uit-

46. Tegen de beslissing tot overlevering staat geen rechtsmiddel open, behoudens beroep in cassatie in het belang der wet (art. 29 lid 2 OW).

47. Het gaat hierbij om EAB's die zijn uitgevaardigd ten behoeve van een strafvervolging en ter uitvoering van een in een andere lidstaat opgelegde vrijheidsbenemende straf of maatregel: Rb. Amsterdam 4 juni 2019, ECLI:NL:RBAMS:2019:4010.

48. Met uitzondering van EAB's die zijn uitgevaardigd door een Duitse rechtbank: bijvoorbeeld Rb. Amsterdam 20 juni 2019, ECLI:NL:RBAMS: 2019:4389 en 4393, Rb. Amsterdam 30 juli 2019, ECLI:NL:RBAMS: 2019:5610 en Rb. Amsterdam 6 augustus 2019, ECLI:NL:RBAMS: 2019:5849

49. Voortbouwend op Rb. Amsterdam 1 december 2016, ECLI:NL:RBAMS: 2016:9311: bijvoorbeeld Rb. Amsterdam 28 mei 2019, ECLI:NL:RBAMS:2019:4102 en 4103, Rb. Amsterdam 11 juli 2019, ECLI:NL:RBAMS:2019:5000 en Rb. Amsterdam 13 augustus 2019, ECLI:NL:RBAMS:2019:6001.

50. Rb. Amsterdam 29 mei 2019, ECLI:NL:RBAMS:2019:3937, 3940 en 3942 en 31 mei 2019, ECLI:NL:RBAMS:2019:4093. In een enkel geval wordt de overleveringsdetentie geschorst onder het stellen van voorwaarden: Rb. Amsterdam 29 mei 2019, ECLI:NL:RBAMS:2019:3944. 
spraken van het Hof van Justitie. ${ }^{51}$ Eenzelfde benadering is herkenbaar bij overleveringsverzoeken uit Letland, België, Griekenland en Frankrijk. In deze zaken geeft de rechtbank de officier van justitie de gelegenheid om vragen te stellen over het risico dat de autoriteit die het EAB heeft uitgevaardigd kan worden onderworpen aan een individuele instructie vanuit de uitvoerende macht en over de mogelijkheid om tegen deze uitvaardiging in rechte op te komen, in het bijzonder met betrekking tot de evenredigheid van de beslissing tot deze uitvaardiging, in een procedure die volledig voldoet aan eisen die voortvloeien uit een effectieve rechtsbescherming. 52

51. Rb. Amsterdam 31 mei 2019, ECLI:NL:RBAMS:2019:3905 en 4093 en Rb. Amsterdam 6 juni 2019, ECLI:NL:RBAMS:2019:4702. Dit betekent overigens dat de overleveringsdetentie van de opgeëiste persoon kan worden verlengd. Dit lijkt verdedigbaar op grond van de uitspraak van het Hof van Justitie van 16 juli 2015, zaak C-237/15 P, Lanigan, ECLI:EU:C:2015:474, punt 64, waarin wordt bepaald dat voortzetting van de overleveringsdetentie van de opgeëiste persoon mogelijk is om de voorwaarden voor de daadwerkelijke overlevering van deze persoon te handhaven zolang geen definitieve beslissing over de tenuitvoerlegging van het $E A B$ is genomen, zelfs wanneer de totale duur van de overleveringsdetentie de termijnen genoemd in art. 17 KEAB (niet buitensporig) overschrijdt.

52. Rb. Amsterdam 28 mei 2019, ECLI:NL:RBAMS:2019:3859, Rb. Amsterdam 4 juni 2019, ECLI:NL:RBAMS:2019:4010, 4412 en 4413 en Rb. Amsterdam 11 juni 2019, ECLI:NL:RBAMS:2019:4106. 